\title{
The Judgement of Craig Newell
}

\author{
IAN WELSH \\ Freelance writer, editor and consultant (Toronto, Canada)
}

A few weeks ago I received the news that my old coach and math teacher, Craig Newell, had died. I haven't written about it till now because I've been thinking of him since then. He was an odd man, spare and lean, with the whippet body of a greyhound, and he had a way of cocking his head when he looked at you which was inevitably parodied every year when the seniors did their annual play.

I spent five years around him, in high school, a boarder in an all boys school. It was an excellent school, well run, with fair rules and no brutality, but I hated the place and was miserable most of the time, though still happier there than I would have been at home. Mr. Newell was my grade 9 math teacher, but I didn't really make a connection with him till a few months into the year.

The standard punishment at school for infractions was what I like to call brutal exercise. What it was exactly varied by the master or prefect who was in charge of the punishment detail, but one that particularly sticks out in my mind is being told to hold heavy wooden chairs over your head and then made to run around the quadrangle till you collapsed. Pushups and situps featured as well, and through most of my teen years I could easily do over a hundred of each. We often used to joke that the strap would have been easier and less painful.

I don't remember what I did to get on that particular punishment detail, but since I didn't feel like doing brutal exercise I talked the master whom I'd offended into letting me run a cross country race happening the next day, which was being supervised by Mr. Newell. Like most folks, the master hated long-distance running and figured it was worse than calisthenics. I found long-distance running easy. So I reported to Mr. Newell and ran the race. I had never run a race before, didn't run more than twice a year in the school's mandatory runs, and having been told that if I didn't put in a credible effort, it 
wouldn't count, came in about half way in the pack of runners. Mr. Newell pulled me aside, asked if I'd ever raced before or practiced, and on hearing I hadn't, suggested I try out for the team.

Now if this was a Hollywood movie, I'd have gone on to be a star. That wasn't the case, but I did join the team, run track and cross-country most years and do well enough to stay on the team.

More to the point, I found I liked running and I started running a lot more than the 2 days a week the team officially met. And if it was a weekday, when school ended I'd swing past Mr. Newell's office and see if he wanted to go for a run too. As often as not, he would, and we'd run for 30 or 40 minutes. Usually they weren't hard runs, we'd pace ourselves just below the point where speech becomes unpleasant, and while we ran we'd talk.

Unlike a lot of coaches, Mr. Newell wasn't also the math teacher as a way to give him something to do-he'd studied math and philosophy in university and he had an excellent and searching mind. He'd often give me nuggets like the Barber's paradox to chew over, or we'd discuss other philosophical questions like how we know what we know, or what moral behaviour is.

Mr. Newell didn't have a lot of answers. He handled me pretty much with the Socratic method. But he did have one question he always asked, that came to define him in my mind. When I'd express disapproval of something someone had done, or someone's beliefs, he'd ask:

"Why do you feel it necessary to not approve?"

And he'd step it back:

"Have they harmed you?" "Have they harmed anyone else?" "Why do you think they did that?" "Why do they believe what they believe?" "Given what they believe, is what they did reasonable?"

And most important of all he'd ask "Does your disapproval do anything to them? Does it do anything to you? Can you affect this situation?"

Mr. Newell was very interested in understanding what people did and why. He wasn't very interested in judging them. And even when he did judge someone, usually because it was his job, he shied violently away from being judgemental.

Mr. Newell didn't let his emotions, didn't let his need to be judgemental and to feel superior to other people, get in the way of his understanding of other people.

Most people, I have come to believe, have a strong need to judge others. To quickly assign to them "good" or "bad" labels. And once they've done so the thinking, the understanding and the empathy dies. Once someone is evil, or bad, or immoral they aren't like us. (Because most of us don't have the honesty to admit our own evil.) At that point, empathy dies. And without empathy there is no understanding-if you cannot walk a mile in someone else's shoes you cannot understand them. (And, I suppose I should point out that understanding one's enemies is the best way to defeat them. Which is why the US loses so much, because it refuses to understand those it fights.)

Now none of this is to say that Mr. Newell thought you should never, ever, judge. He was, after all, a teacher. He was in a job where you have to judge. But he felt you 
should judge carefully, only as far as the evidence goes, and not let it spill over into your other judgements of the people involved. I have come to simplify this as learning how to "judge without being judgemental". More than that it implies that moral disapproval, moral judgements, in particular, should be used sparingly and that once used shouldn't spill over. An example would be that many people (correctly) see Osama Bin Laden as a mass murderer and therefore evil. But that spills over, and they become unwilling to grant that he is an extremely brave man who led troops from the front, that he is a very intelligent man whose plans have been more effective than those of most leaders he's been fighting, or that he, say, loves his family and is genuinely pious, generous and godfearing. Yet the evidence is that he's all of those things.

When you judge too quickly, you get things wrong. When you judge too broadly, you blind yourself to what a person actually is.

And really, why do we love to judge so much? Because it makes us feel better about ourselves. In our contempt for those we judge we can pretend that we're nothing like them, that we aren't complicit in the same evils, that we have never harbored the same thoughts, or perhaps even acted on them. Being judgemental makes us feel good about ourselves but the price is that it blinds us, both to those we judge, and to ourselves. In writing off understanding others, we write off understanding ourselves.

And ultimately, that is the lesson I learned from Mr. Newell in those hundreds of hours of running.

\section{Always understand before judging}

Judge sparingly. Is it really necessary to judge this person? Do their beliefs or actions harm anyone but themselves? Is it your place to judge?

When you must judge, judge without being judgemental.

Listen to what your judgement says about you, more than what it says about others.

Satisfaction in condemning another is a danger sign that you may be using the condemnation to blind yourself, to yourself.

Don't judge large, judge small and specific.

I don't know what comes after this life, but if there is an afterlife, if there is a judging of men and women, I hope that Mr. Newell is judged himself as he judged others. And may it be laid on his scale, that he was kind to a scared and lonely teenager when almost no one else was, and saw the good in that boy that few others did.

\section{Acknowledgments}

This article was first published on the blog FireDogLake on Saturday April 19, 2008 4:00 pm. Responses to this article published on that blog are well worth a read and may be accessed at: http://firedoglake.com/2008/04/19/the-judgement-of-craig-newell/\#Respond. 
IAN WELSH

\begin{abstract}
About the author
Ian Welsh is a freelance writer, editor and consultant. He has been the managing editor of Firedoglake (www.firedoglake.com) and the Agonist (agonist.org). You can read more about Ian at .ianwelsh.net/about/
\end{abstract}

(c) Copyright 2009. The author IAN WELSH assigns to the University of Alberta and other educational and non-profit institutions a non-exclusive license to use this document for personal use and in courses of instruction provided that the article is used in full and this copyright statement is reproduced. The author also grants a non-exclusive license to the University of Alberta to publish this document in full on the World Wide Web, and for the document to be published on mirrors on the World Wide Web. Any other usage is prohibited without the express permission of the author. 